\title{
Metastatic Neuroendocrine Neoplasm
}

National Cancer Institute

\section{Source}

National Cancer Institute. Metastatic Neuroendocrine Neoplasm. NCI Thesaurus. Code C156485.

A neuroendocrine neoplasm that has spread from its original site of growth to another anatomic site. 